\title{
Endothelial Progenitor Cells and the Diabetic Paradox Current Knowledge and Therapeutic Perspectives
}

\author{
Carla Costa ${ }^{* 1,2}$ \\ ${ }^{I}$ Department of Biochemistry (U38-FCT), Faculty of Medicine of the University of Porto, Porto, Portugal; ${ }^{2}$ Laboratory \\ for Molecular Cell Biology, Faculty of Medicine of the University of Porto, Porto, Portugal
}

\begin{abstract}
The discovery of postnatal vasculogenesis and of the important roles played by bone marrow-derived Endothelial Progenitor Cells was a landmark in vascular biology that forever has changed the concept of neovascularization. Diabetes associated vascular complications involve distinct modifications in neovascular formation, which is reduced in cardiovascular disease and increased in diabetic retinopathy, defining the diabetic paradox. The vasculogenic process seems to play a central dual role in these alterations: by one side dysfunctional EPCs impair endothelial regeneration in peripheral vasculopathy and on the other hand alterations in EPCs are involved in increased retinal vessel growth in diabetic retinopathy. Although still under investigation, these divergent features seem related to a differential response of progenitor cells to ischemic-induced depletion/induction of angiogenic factors. Due to the importance of vasculogenesis, therapeutic interventions targeting EPCs in diabetic vascular complications arose as a potential tool. However, scarce information has been disclosed regarding the safety and harmful side effects of these therapies. Future research is mandatory in order to further elucidate the complex mechanisms governing the diabeticvasculogenic paradigm, bringing also novel insights into the potential therapeutic usefulness of EPCs.
\end{abstract}

Keywords: Endothelial Progenitor Cells, diabetes, endothelial dysfunction, cardiovascular disease, diabetic retinopathy.

\section{ENDOTHELIAL PROGENITOR CELLS (EPCs) AND POSTNATAL VASCULOGENESIS - A FALLEN DOG- MA VASCULOGENESIS VS ANGIOGENESIS}

Blood vessels constitute the first organ in the embryo and form the largest network in our body [1]. Two important processes drive the development of the vascular system, vasculogenesis and angiogenesis. Vasculogenesis occurs during early embryonic development and mediates the de novo vessel formation from Endothelial Progenitor Cells (EPCs) or angioblasts of mesodermal origin, which differentiate into mature endothelial cells (ECs) assembling into a primary capillary plexus [1]. Subsequently, this primitive vascular network expands by angiogenesis, where new blood vessels arise from the proliferation and migration of the pre-existing ECs [2,3]. During several decades it was thought that in the adult, vascular growth and remodelling was exclusively dependent on the activation of angiogenesis, and that the process of vasculogenesis was restricted to embryonic life. This long-lasting belief has come to an end around ten years ago.

\section{EPCs AND POSTNATAL VASCULOGENESIS: FACT OR FICTION?}

The quest for EPCs and vasculogenesis in adulthood took several decades, until in 1997 Asahara and collaborators started unraveling the issue. They have isolated for the first

*Address correspondence to this author at the Laboratory for Molecular Cell Biology, Faculty of Medicine of the University of Porto, Al. Prof. Hernâni Monteiro, 4200-319 Porto, Portugal; Tel: +351 225513654;

Fax: +351 225513655; E-mail: carcosta@med.up.pt time a population of angioblast-like $\mathrm{CD} 34^{+}$circulating EPCs from adult peripheral blood (PB). When cultured in vitro these cells presented increased proliferation rate and exhibited endothelial morphological and functional properties [4]. However, besides the functional characteristics of these endothelial progenitor-like cells, some questions concerning their true identity brought controversy into the field. For instance, besides exhibiting a high proliferative capacity, this cell population did not display any other specific phenotypic and/or functional characteristics. In fact, the CD34 antigen used for cell isolation is also present in sub-groups of hematopoietic stem/progenitor cells and mature ECs and does not specifically discriminate EPCs. Nevertheless, the pioneering work of Asahara et al. was the first to suggest that the process of vasculogenesis could occur in adult life. Their study marked the beginning of the end of a prevailing dogma denying the existence of postnatal vasculogenesis. The postAsahara Era was fruitful in essential research presenting evidence for the existence of postnatal EPCs and their role in neovascular processes. Several studies demonstrated that EPCs residing in the bone marrow (BM) could be mobilized to the peripheral circulation, migrate to neoangiogenic sites and partake in vivo in the development of vascular networks, by differentiating into functional, mature ECs [5-8]. EPCs mobilization from the $\mathrm{BM}$ and homing to neovascular foci occurred in response of progenitor cells to specific angiogenic stimuli. It has been reported that increased levels of chemokines including, the Vascular Endothelial Growth Factor (VEGF) and Stromal Derived Factor (SDF)-1, induce several cellular pathways/mechanisms which promote EPCs release and mobilization from the $\mathrm{BM}$ and recruitment to 
neovascular foci $[6,9,10]$. Although all the mechanisms involved are yet to be completely elucidated, it is thought that peripheral tissue secretion of VEGF induces the release of EPCs from the BM microenvironment, through the activation of matrix metalloproteinase (MMP)-9, which by altering EPCs interactions with BM stromal cells allow them to disengage [11]. Additionally, activation of BM endothelial Nitric Oxide Synthase (eNOS) and consequent increased eNO levels stimulates the passage of EPCs through BM sinusoidal endothelium and their entrance into the blood stream, where they are further recruited to neoangiogenic foci $[9,12]$. Besides EPCs differentiation into mature ECs upon arrival to neovascular sites, this cell population may additionally contribute to neovascular formation through the paracrine release of pro-angiogenic growth factors, promoting the enhancement of local angiogenesis $[13,14]$.

\section{CHARACTERIZATION OF ADULT EPCs: PHENO- TYPIC AND FUNCTIONAL PROPERTIES}

Since the initial proposal that EPCs and postnatal vasculogenesis occurred in adulthood, much controversy has accompanied this field over time. One of the main arguments concerned the phenotypic characterization of EPCs, since their isolation and identification were mostly hampered by the lack of EPCs-specific surface markers. Some consensus has been reached and EPCs were considered to be the cell population characterized by the concomitant expression of: the early hematopoietic stem cell markers CD34 and CD133 (former AC133) and VEGF receptor-2 (VEGFR-2) [13, 15, 16]. Upon differentiating in ECs, EPCs lose the expression of CD133 and start exhibiting a classical EC morphology and characteristics, such as the expression of endothelial markers (von Willebrand factor and vascular endothelial (VE)-cadherin) and the capacity to uptake acetylated lowdensity lipoprotein (LDL) [5, 15]. Novel evidence has suggested that two distinct $\mathrm{CD} 34^{+} \mathrm{CD} 133^{+} \mathrm{VEGFR}^{+}$ populations of EPCs may be grown out from adult peripheral blood PB mononuclear cells. Although the biology of these endothelial progenitor-like cells is not fully understood, they seem to present distinct phenotypes and cell surface antigens and display diverse vasculogenic features in vitro $[17,18]$. In culture, one EPC population seems to form "Early Outgrowth Colonies" (EOCs), whereas the other gives rise to "Late Outgrowth Colonies" (LOCs). EOCs and LOCs are primarily characterized based on their morphology and chronology of appearance following in vitro culture. EOCs appear in culture within seven days, exhibit spindle-shaped morphology emanating from a central cluster of cells and have a peak growth at two-three weeks after which they cannot be further expanded $[17,18]$. LOCs generally appear after three weeks and exhibit a "classic endothelial" phenotype, having an increased expansion potential. LOCs seem more capable of in vitro morphogenesis into capillary tubes, the best approximate true definition of an EPC, a competent progenitor cell whose terminally differentiated progeny are mature ECs [17-19]. This capillary-forming capacity is minimal or nonexistent within EOCs, which is thought to have a paracrine role by supporting LOCs differentiation and capillary formation, through the release of pro-angiogenic molecules and by inducing the activation of MMPs [17, 18, 20]. Phenotypically, EOCs additionally express the monocyte/macrophage marker CD14, which is absent among mature LOCs, and both populations may concomitantly express CD34, CD133 and VEGFR-2 [16, 20]. Nonetheless, most of the reports involving in vitro and in vivo EPCs studies have performed cell isolation based on the classic antigen triad, CD34/CD133/VEGFR-2, and in further cell characterization do not usually make a distinction between EOCs and LOCs, analyzing both populations as a whole. However, novel findings have shaken this field since it was demonstrated the existence of novel subsets of progenitor cells with an involvement in vascular repair. It was recently reported the presence in PB of a novel stem cell population which lack the $\mathrm{CD} 34$ antigen and is able to differentiate into the "classic" CD $34^{+} \mathrm{CD} 133^{+} \mathrm{EPCs}$, which then acquire a more mature endothelial phenotype. Althought the role of these CD $34^{-} \mathrm{CD} 133^{+}$VEGFR- $2^{+}$cells is still under investigation, it was suggested that they may preferentially home to ischemic sites and promote more potent endothelial regeneration than the defined "classic" EPCs [21]. Additionally, other populations with endothelial repair capabilities which express additional cell surface markers, including the receptor for SDF-1, the chemokine (C-X-C motif) receptor (CXCR)-4 have also been identified [22]. Further research will most certainly describe additional EPCs subpopulation based on new findings regarding new patterns of antigen expression.

\section{VASCULOGENESIS AND NEOVASCULAR FORMA- TION IN PATHOPHYSIOLOGICAL PROCESSES}

Studies in experimental models, where CD $34^{+}$CD $133^{+}$VEGR $-2^{+}$EPCs were evaluated, demonstrated that postnatal vasculogenesis could take place under certain physiological and pathological settings such as, vascular endothelial homeostasis and repair $[6,23]$, wound healing [7], bone regeneration [24], myocardial and limb ischemia $[6,7,25]$, and tumor neovascularisation [6-8]. A single paper has brought some controversy, by suggesting that EPCs did not contribute to tumor-associated neovascular formation, in an experimental tumorigenic model [26]. Nonetheless, research in adult patients has corroborated the evidence for postnatal vasculogenesis provided by most experimental data. It was demonstrated that EPCs recruitment and homing may occur after vascular trauma in burn individuals [27], following acute myocardial infarction [28] and that a percentage of BM-derived EPCs can contribute to human tumour-associated neovasculature [29]. It has also been proposed that other of BM-derived hematopoietic/myeloid progenitor cells, named as accessory cells, could be corecruited to tumour neoangiogenesis foci, and support vascular growth in a paracrine fashion [8, 14, 30, 31]. It was further reported that a subpopulation of $\mathrm{CD} 34^{-} \mathrm{AC} 133^{+}$ EPCs, home preferentially to sites of coronary lesions responding to ischemia and vascular injury and promoting endothelial regeneration more potently than the $\mathrm{CD} 4^{+} \mathrm{CD} 133^{+}$EPC population [21]. Overall, several EPC subsets and lineages of precursor cells may be differentially recruited in diverse pathophysiological conditions, contributing synergistically to vasculogenic neovascularization.

\section{RELEVANCE OF EPCS IN CLINICAL SETTINGS}

As an increasing body of evidence has definitely revealed the important role of EPCs on postnatal neovascularization 
in multiple conditions; a growing interest into their potential use in the clinical setting has emerged. Is it then possible to use EPCs as clinical tool? It has been suggested that EPCs could have a potential use as, prognostic factor [32-35], as cell-based therapy [36], as therapeutic outcome predictor and/or as disease biomarker [37-41]. In fact, as EPCs play an important role on tumour neovascularization, it was suggested that evaluating the number of circulating CD $34^{+}$CD $133^{+}$VEGFR $-2^{+}$EPCs in cancer patients, could be a potential prognostic factor and an indirect assessment of the neovascular potential of a growing tumour [32-34]. In addition and due to its vasculogenic potential, it was proposed that EPCs transplantation into ischemic tissues could be an efficient treatment approach to promote vessel formation and improve blood perfusion [36]. It was also anticipated that measuring EPCs in circulation would constitute an alternative approach to monitor the therapeutic efficacy of anti-angiogenesis treatment schedules [37]. Additionally, cumulative evidence has suggested that the quantification of circulating EPCs could represent a novel non-invasive surrogate biomarker for vascular homeostasis/dysfunction in cardiovascular disease (CVD) associated to diabetes [38-41]. However, diabetes represents a paradoxal puzzle, since patients face simultaneously poor vessel growth in ischemic heart and limbs and increased neovascularization in the retina [42, 43]. Surprinsingly, EPCs and the vasculogenic process seem to play a distinct dual role, contributing both to decreased and increased neovascular formation associated to diabetes.

\section{VASCULOGENESIS AND THE DIABETIC PARADOX - THE LINK GROWS STRONGER}

Diabetes mellitus (DM) is a common costly chronic disease and its incidence is rapidly increasing worldwide. Individuals with type 2 DM (T2DM) account for most of this augmentation in the general population. An important part of this rise is attributed to changing living conditions, including overweight and obesity, sedentary behaviour, and unhealthy lifestyle [44]. Diabetes profoundly affects vascular biology and its associated complications are related to impairment of macro- and microvascular beds, causing significant morbidity and mortality [38, 39, 45]. Diabetic vascular alterations in different organs occur by distinct modifications in neovascular formation, which is decreased in systemic CVD and increased in diabetic retinopathy (DR). This diabetic paradox has been attributed to the differential regulation of neovascular mechanisms, which responde differently to ischemia in diabetic conditions [46]. This seems to be the case of the vasculogenic process, which is decreased systemically and increased in the diabetic retina. Although the complex mechanisms governing this diabeticvasculogenic paradox are still under investigation, novel evidence connecting alterations in EPCs to diabetic vascular complications will be further discussed.

\section{DIABETIC VASCULOPATHY AND ALTERED VAS- CULOGENESIS}

Diabetes is characterized by a systemic pro-inflammatory state and generalized endothelial dysfunction (ED). ED ultimately represents the unbalance between endothelium injury and the endogenous capacity for endothelial repair [47]. It was proposed that diabetes, and the underlying hyperglycemia, insulin resistance, hypertension and oxidative stress, simultaneously promote endothelial damage and affect deleteriously EPCs functions, thus preventing efficient vascular repair and favoring the development of atherosclerotic lesions [40]. Amongst all these risk factors, increased glycemic levels and excessive oxidative stress seem to be the major causal factors underlying both endothelial injury and vasculogenic impairment [48]. Nonetheless, the complex interplay between all the aforementioned conditions is thought to sinergistically decrease endothelial regeneration by altering EPCs biological activities, such as: reducing EPCs migration [49, 50]; impairing their mobilization [51-55]; promoting premature senescence [56]; inhibiting integrative and morphogenic capacities (defective adhesion, colony-forming ability and tubule assembly) [39, 57] and inducing EPCs apoptosis [58, 59]. These alterations on EPCs features have been associated with deficient endogenous reendothelialization/neovascularization, being a potential indicator of diabetic CVD severity $[55,60,61]$. In conjunction with deficient EPCs functions, the production of chemotactic/angiogenic factors is inhibited in diabetic peripheral ischemic tissues; contributing both alterations to poor collateral formation and insufficient perfusion. It has been shown that the expression of angiogenic factors such as, VEGF and Hypoxia-Inducible Factor (HIF)-1 are reduced in the hearts of diabetic patients during acute coronary syndromes [62]. Recently, it was also demonstrated that following the onset of acute myocardial infarction in T2DM patients, the numbers of $\mathrm{CD}_{13} 3^{+}$progenitor cells are reduced and their chemotactic responsiveness attenuated [63]. Both the defective expression of angiogenic factors and the dysfunction in EPCs account for the delayed post-ischaemic vascular healing and myocardial recovery in patients with DM. Diabetic cardiomyopathy is also characterized by an early and progressive decline in myocardial VEGF expression and reduced circulating EPCs, which contributes to diminished capillary density, decreased myocardial perfusion and impaired contractility [64]. A significant decline in circulating EPCs was also reported in diabetic patients with peripheral arterial disease (PAD), particularly in individuals with ischemic foot lesions. EPCs levels correlated with the ankle-brachial index, the most objective diagnostic and prognostic test for lower extremity arterial disease. It was also demonstrated that decreased EPCs closely correlated with the severity of both carotid and lower limb atherosclerosis. Higher degrees of carotid stenosis, as well as, worse stages of leg claudication and ischemic lesions, were associated with lower levels of EPCs. This suggested that EPCs counts could be considered a valuable marker for atherosclerotic involvement [60]. Additionally, EPCs isolated from diabetic patients with PAD exhibited poor endothelial differentiation capacity, impaired proliferation and deficient adhesion to mature endothelium [39, 65]. Recently, a study has evaluated the circulating levels of the CD34CD $133^{+}$VEGFR-2 ${ }^{+}$EPCs in diabetic patients with CVD, revealing a decrease in this subpopulation caused by diabetes-induced apoptosis [66]. Similarly, it was also proposed that a subset of CXCR-4 ${ }^{+}$ progenitor cells with vascular repair capability, were decreased in the PB of T2DM patients [61]. In ischemic conditions, the reduced levels of $\mathrm{CXCR}-4^{+}$precursors may 
responde poorly to SDF-1, preventing their efficient mobilization and recruitment from the BM niche to ischemic sites. In addition, it seems relevant to mention novel data disclosing the effects of hyperglycemia in EPCs in intrauterine life. Interestingly, the exposure to high glucose levels in a diabetic intrauterine environment was shown to diminish the clonogenic potential of neonatal EPCs, providing a new insight into the long-term cardiovascular complications observed in newborns of diabetic pregnancies [67]. Even though other relevant aspects of EPCs biology in diabetic vasculopathy remain to be defined, future research will most certainly bring novel insights into the potential diagnostic, prognostic and/or therapeutic usefulness for the several EPCs subsets in diabetes.

\section{EPCs AND DIABETIC RETINOPATHY}

High blood glucose is an extremely detrimental factor for the retina microvasculature. Hyperglycemic damage results in increased permeability, blood and serum leakage to the extravascular space, and progressive decline in retinal blood flow. Retinal ischemia and release of angiogenic factors stimulate the proliferation of microvessels, leading to proliferative DR (PDR). New vessel growth destroys the normal retinal architecture and may hemorrhage, easily causing bleeding into the eye, which ultimately impairs vision [68]. Up until recently, angiogenesis was thought to be the only process governing aberrant diabetic retinal neovascularization. However, retinal ischemia-induced release of specific factors may stimulate both local growth of vessels and the mobilization of BM-derived EPCs, which contribute to the development of PDR. Initial studies in PDR experimental models have shown that EPCs could be recruited to retinal sites of ischemic injury, playing a role in the revascularization of the retina $[69,70]$. Although the mechanisms underlying EPCs roles are still under evaluation, it was reported they may be mobilized and recruited to the diabetic retina in response to local secretion of VEGF and SDF-1. Moreover, studies in PDR experimental models and in diabetic patients presenting this complication have shown that SDF-1 seems to be the most important chemokine involved in the mobilization of EPCs to the retina $[71,72]$. In addition, the concentration of SDF-1 increases with the severity of DR, as evaluated in vitreous samples of T2DM individuals [72]. It seems however counterintuitive, that diabetic vascular complications, as PDR and PAD, may affect the same patient, and alterations in EPCs exhibit opposing roles. A study has attempted to disclose differential EPCs alterations and features in T2DM patients with DR and with various combinations of PAD and DR [65]. This report has demonstrated that while $\mathrm{CD} 34^{+} \mathrm{KDR}^{+} \mathrm{EPCs}$ and endothelial differentiation of cultured progenitors were selectively reduced in PAD patients, generic $\mathrm{CD} 34^{+}$progenitors were also reduced in DR patients, but presented instead higher clonogenic potential and enhanced endothelial differentiation in culture. Corroborating this observation it was also shown that EPCs cultured from PB of patients with T1DM and PDR displayed increased clonogenic potential [73]. Recently, another report brought more important information on the role of different progenitor cells in various stages of DR in patients with T1DM. Overall, this study has demonstrated that non-proliferative retinopathy, correlated with a reduction of EPCs, however in
PDR there was a dramatic increase of mature EPCs [74]. Recent findings in diabetic patients have corroborated the gathered experimental data, demonstrating that BM-derived $\mathrm{CD}_{133^{+}}$EPCs, as well as, CD14 ${ }^{+}$monocytes could be mobilized to diabetic epiretinal membranes, contributing to vasculogenesis in PDR [75]. Taken together, these data strengthen the importance of EPCs in the development of human PDR, highlighting the crucial role played by both the local retinal and the systemic environment.

\section{THERAPEUTIC IMPLICATIONS}

Given the comprehensive role of EPC alterations in diabetes complications, modulation of the levels/function of EPCs may be considered a potential therapeutic strategy. Many vasculoprotective agents provided with beneficial cardiovascular effects, such as statins and thiazolidinediones (peroxisome proliferators-activated receptor-gamma; PPAR$\gamma$ agonists), have been shown to improve endotheliumdependent vascular function and prevent atherosclerotic disease progression, by restoring EPCs properties and actions [76, 77]. However one might not neglect that diabetic patients frequently display both peripheral decrease in neovascularization and a retinal increase on vessel growth. This might have a critical impact regarding potential therapies and has raised multiple questions that only future clinical research will answer: What would be the consequences on the therapeutic interventions having as target EPCs? Is it safe to administer ex-vivo an expanded/enriched EPC pool in diabetic peripheral vasculopathy and cardiomyopathy, without exacerbating vessel growth in the retina? Even though diabetics have altered EPCs function, would they endogeneously respond to pharmacological agents? What would be the peripheral impact of blocking EPCs functions in the retina? Althougth there are no conclusive answers on the safety on EPCs therapies and of their potential undesidered side effects, preclinical and clinical studies have highted that autologous transplantation of several stem and progenitor cell populations ameliorated diabetic peripheral vascular complications [78, 79]. In order to prevent harmful side effects, it is first needed to go deeper into the molecular events accompanying alterations in diabetic vascular complications, unveiling the complex mechanisms governing this diabetic-vasculogenic paradox.

\section{CONCLUDING REMARKS}

According to the novel paradigms of neovascular events, $\mathrm{BM}$ is a reservoir of immature endothelial progenitor cells that, once in the bloodstream, are recruited to partake in the regeneration and repair of injured endothelial beds. Besides the initially identified population of $\mathrm{CD} 34^{+} \mathrm{AC} 133^{+}$VEGFR$2^{+}$EPCs, other subsets of EPCs and progenitor cells with vascular repair capability have been described. We have discussed the most recent data demonstrating that dysfunctions of several EPCs subpopulations may have a prominent role in the pathogenesis of all diabetes complications. Both the decrease and increase of neovascular formation in diabetes seem differentially regulated by altered EPCs, which respond selectively to the local depletion/accumulation of growth factors, explaining the reasons why peripheral ischemia cannot stimulate EPCs recruitment, in opposition to what occurs in the retina. Aware that this 
picture is far from being complete, since novel parts of this complex puzzle need to be disclosed, both concerning the identification and role of additional EPCs populations and the efficient use of therapeutic approaches usings EPCs as major target. Although is crucial to further unveil the diabetic-vasculogenic paradox we may provokingly ask, is it all in the blood? Only the future will answer.

\section{REFERENCES}

[1] Risau, W.; Flamme, I. Vasculogenesis. Annu. Rev. Cell. Dev. Biol., 1995, 11, 73-91.

[2] Folkman, J. What is the role of endothelial cells in angiogenesis? Lab. Invest., 1984, 51(6), 601-4.

[3] Risau, W. Mechanisms of angiogenesis. Nature, 1997, 386(6626), 671-4.

[4] Asahara, T.; Murohara, T.; Sullivan, A.; Silver, M.; van der Zee, R.; Li, T.; Witzenbichler, B.; Schatteman, G.; Isner, JM. Isolation of putative progenitor endothelial cells for angiogenesis. Science, 1997, 275(5302), 964-7.

[5] Shi, Q.; Rafii, S.; Wu, MH.; Wijelath, ES.; Yu, C.; Ishida, A.; Fujita, Y.; Kothari, S.; Mohle, R.; Sauvage, LR.; Moore, MA.; Storb, RF.; Hammond, WP. Evidence for circulating bone marrowderived endothelial cells. Blood, 1998, 92(2), 362-7.

[6] Asahara, T.; Takahashi, T.; Masuda, H.; Kalka, C.; Chen, D.; Iwaguro, H.; Inai, Y.; Silver, M.; Isner, JM. VEGF contributes to postnatal neovascularization by mobilizing bone marrow-derived endothelial progenitor cells. EMBO J., 1999, 18(14), 3964-72.

[7] Asahara, T.; Masuda, H.; Takahashi, T.; Kalka, C.; Pastore, C.; Silver, M.; Kearne, M.; Magner, M.; Isner, JM. Bone marrow origin of endothelial progenitor cells responsible for postnatal vasculogenesis in physiological and pathological neovascularization. Circ. Res., 1999, 85(3), 221-8.

[8] Lyden, D.; Hattori, K.; Dias, S.; Costa, C.; Blaikie, P.; Butros, L.; Chadburn, A.; Heissig, B.; Marks, W.; Witte, L.; Wu, Y.; Hicklin, D.; Zhu, Z.; Hackett, NR.; Crystal, RG.; Moore, MA.; Hajjar, KA.; Manova, K.; Benezra, R.; Rafii, S. Impaired recruitment of bonemarrow-derived endothelial and hematopoietic precursor cells blocks tumor angiogenesis and growth. Nat. Med., 2001, 7(11), 1194-01.

[9] Aicher, A.; Zeiher, AM.; Dimmeler, S. Mobilizing endothelial progenitor cells. Hypertension, 2005, 45(3), 321-5.

[10] Smythe, J.; Fox, A.; Fisher, N.; Frith, E.; Harris, AL.; Watt, SM. Measuring angiogenic cytokines, circulating endothelial cells, and endothelial progenitor cells in peripheral blood and cord blood: VEGF and CXCL12 correlate with the number of circulating endothelial progenitor cells in peripheral blood. Tissue. Eng. Part. C. Methods., 2008, 14(1), 59-67.

[11] Heissig, B.; Hattori, K.; Dias, S.; Friedrich, M.; Ferris, B.; Hackett, NR.; Crystal, RG.; Besmer, P.; Lyden, D.; Moore, MA.; Werb, Z.; Rafii, S. Recruitment of stem and progenitor cells from the bone marrow niche requires MMP-9 mediated release of kit-ligand. Cell, 2002, 109(5), 625-37.

[12] Aicher, A.; Heeschen, C.; Mildner-Rihm, C.; Urbich, C.; Ihling, C.; Technau-Ihling, K.; Zeiher, AM.; Dimmeler, S. Essential role of endothelial nitric oxide synthase for mobilization of stem and progenitor cells. Nat Med., 2003, 9(11), 1370-6.

[13] Hristov, M.; Erl, W.; Weber, PC. Endothelial progenitor cells: isolation and characterization. Trends. Cardiovasc. Med., 2003, 13(5), 201-6.

[14] Grunewald, M.; Avraham, I.; Dor, Y.; Bachar-Lustig, E.; Itin, A.; Jung, S.; Chimenti, S.; Landsman, L.; Abramovitch, R.; Keshet, E. VEGF-induced adult neovascularization: recruitment, retention, and role of accessory cells. Cell, 2006, 124(1), 175-89.

[15] Peichev, M.; Naiyer, AJ.; Pereira, D.; Zhu, Z.; Lane, WJ.; Williams, M.; Oz, MC.; Hicklin, DJ.; Witte, L.; Moore, MA.; Rafii, S. Expression of VEGFR-2 and AC133 by circulating human CD34(+) cells identifies a population of functional endothelial precursors. Blood, 2000, 95(3), 952-8.

[16] Shmelkov, SV.; Butler, JM.; Hooper, AT.; Hormigo, A.; Kushner, J.; Milde, T.; St Clair, R.; Baljevic, M.; White, I.; Jin, DK.; Chadburn, A.; Murphy, AJ.; Valenzuela, DM.; Gale, NW.; Thurston, G.; Yancopoulos, GD.; D'Angelica, M.; Kemeny, N.; Lyden, D.; Rafii, S. CD133 expression is not restricted to stem cells, and both CD133+ and CD133- metastatic colon cancer cells initiate tumors. J. Clin. Invest., 2008, 118(6), 2111-20.

[17] Gulati, R.; Jevremovic, D.; Peterson, TE.; Chatterjee, S.; Shah, V.; Vile, RG.; Simari, RD. Diverse origin and function of cells with endothelial phenotype obtained from adult human blood. Circ. Res., 2003, 93(11), 1023-5.

[18] Hur, J.; Yoon, CH.; Kim, HS.; Choi, JH.; Kang, HJ.; Hwang, KK.; Oh, BH.; Lee, MM.; Park, YB. Characterization of two types of endothelial progenitor cells and their different contributions to neovasculogenesis. Arterioscler. Thromb. Vasc. Biol., 2004, 24(2), 288-93.

[19] Yoder, MC.; Mead, LE.; Prater, D.; Krier, TR.; Mroueh, KN.; Li, F.; Krasich, R.; Temm, CJ.; Prchal, JT.; Ingram, DA. Redefining endothelial progenitor cells via clonal analysis and hematopoietic stem/progenitor cell principals. Blood, 2007, 109(5), 1801-9.

[20] Yoon, CH.; Hur, J.; Park, KW.; Kim, JH.; Lee, CS.; Oh, IY., Kim, TY.; Cho, HJ.; Kang, HJ.; Chae, IH.; Yang, HK.; Oh, BH.; Park, YB.; Kim, HS. Synergistic neovascularization by mixed transplantation of early endothelial progenitor cells and late outgrowth endothelial cells: the role of angiogenic cytokines and matrix metalloproteinases. Circulation, 2005, 112(11), 1618-27.

[21] Friedrich, EB.; Walenta, K.; Scharlau, J.; Nickenig, G.; Werner, N. CD34-/CD133+/VEGFR-2+ endothelial progenitor cell subpopulation with potent vasoregenerative capacities. Circ. Res., 2006, 98(3), e20-5.

[22] Egan, CG.; Lavery, R.; Caporali, F.; Fondelli, C.; Laghi-Pasini, F.; Dotta, F.; Sorrentino, V. Generalised reduction of putative endothelial progenitors and CXCR4-positive peripheral blood cells in type 2 diabetes. Diabetologia, 2008, 51(7), 1296-305.

[23] Shantsila, E.; Watson, T.; Lip, GY. Endothelial progenitor cells in cardiovascular disorders. J. Am. Coll. Cardiol., 2007, 49(7), 74152.

[24] Matsumoto, T.; Mifune, Y.; Kawamoto, A.; Kuroda, R.; Shoji, T.; Iwasaki, H.; Suzuki, T.; Oyamada, A.; Horii, M.; Yokoyama, A.; Nishimura, H.; Lee, SY.; Miwa, M.; Doita, M.; Kurosaka, M.; Asahara, T. Fracture induced mobilization and incorporation of bone marrow-derived endothelial progenitor cells for bone healing. J. Cell. Physiol., 2008, 215(1), 234-42.

[25] Takahashi, T.; Kalka, C.; Masuda, H.; Chen, D.; Silver, M.; Kearney, M.; Magner, M.; Isner, JM.; Asahara, T. Ischemia- and cytokine-induced mobilization of bone marrow-derived endothelial progenitor cells for neovascularization. Nat. Med., 1999, 5(4), 4348.

[26] Purhonen, S.; Palm, J.; Rossi, D.; Kaskenpää, N.; Rajantie, I.; YläHerttuala, S.; Alitalo, K.; Weissman, IL.; Salven, P. Bone marrowderived circulating endothelial precursors do not contribute to vascular endothelium and are not needed for tumor growth. Proc. Natl. Acad. Sci. USA., 2008, 105(18), 6620-6625.

[27] Gill, M.; Dias, S.; Hattori, K.; Rivera, ML.; Hicklin, D.; Witte, L.; Girardi, L.; Yurt, R.; Himel, H.; Rafii, S. Vascular trauma induces rapid but transient mobilization of VEGFR2(+)AC133(+) endothelial precursor cells. Circ. Res., 2001, 88(2), 167-74.

[28] Shintani, S.; Murohara, T.; Ikeda, H.; Ueno, T.; Honma, T.; Katoh, A.; Sasaki, K.; Shimada, T.; Oike, Y.; Imaizumi, T. Mobilization of endothelial progenitor cells in patients with acute myocardial infarction. Circulation, 2001, 103(23), 2776-9.

[29] Peters, BA.; Diaz, LA.; Polyak, K.; Meszler, L.; Romans, K.; Guinan, EC.; Antin, JH.; Myerson, D.; Hamilton, SR.; Vogelstein, B.; Kinzler, KW.; Lengauer, C. Contribution of bone marrowderived endothelial cells to human tumor vasculature. Nat. Med., 2005, 11(3), 261-2.

[30] Kaplan, RN.; Riba, RD.; Zacharoulis, S.; Bramley, AH.; Vincent, L.; Costa, C.; MacDonald, DD.; Jin, DK.; Shido, K.; Kerns, SA.; Zhu, Z.; Hicklin, D.; Wu, Y.; Port, JL.; Altorki, N.; Port, ER.; Ruggero, D.; Shmelkov, SV.; Jensen, KK.; Rafii, S.; Lyden, D. VEGFR1-positive haematopoietic bone marrow progenitors initiate the pre-metastatic niche. Nature, 2005, 438(7069), 820-7.

[31] De Palma, M.; Venneri, MA.; Galli, R.; Sergi Sergi, L.; Politi, LS.; Sampaolesi, M.; Naldini, L. Tie2 identifies a hematopoietic lineage of proangiogenic monocytes required for tumor vessel formation and a mesenchymal population of pericyte progenitors. Cancer Cell, 2005, 8(3), 211-26.

[32] Ho, JW.; Pang, RW.; Lau, C.; Sun, CK.; Yu, WC.; Fan, ST.; Poon, RT. Significance of circulating endothelial progenitor cells in hepatocellular carcinoma. Hepatology, 2006, 44(4), 836-43. 
[33] Pircher, A.; Kähler, CM.; Skvortsov, S.; Dlaska, M.; Kawaguchi, G.; Schmid, T.; Gunsilius, E.; Hilbe, W. Increased numbers of endothelial progenitor cells in peripheral blood and tumor specimens in non-small cell lung cancer: a methodological challenge and an ongoing debate on the clinical relevance. Oncol. Rep., 2008, 19(2), 345-52.

[34] Naik, RP.; Jin, D.; Chuang, E.; Gold, EG.; Tousimis, EA.; Moore, AL.; Christos, PJ.; de Dalmas, T.; Donovan, D.; Rafii, S.; Vahdat, LT. Circulating endothelial progenitor cells correlate to stage in patients with invasive breast cancer. Breast Cancer Res. Treat., 2008, 107(1), 133-8.

[35] Goon, PK.; Lip, GY.; Stonelake, PS.; Blann, AD. Circulating endothelial cells and circulating progenitor cells in breast cancer: relationship to endothelial damage/dysfunction/apoptosis, clinicopathologic factors, and the Nottingham Prognostic Index. Neoplasia, 2009, 11(8), 771-9.

[36] Sepúlveda, P.; Martinez-León, J.; García-Verdugo, JM. Neoangiogenesis with endothelial precursors for the treatment of ischemia. Transplant. Proc., 2007, 39(7), 2089-94.

[37] DePrimo, SE.; Bello, C. Surrogate biomarkers in evaluating response to anti-angiogenic agents: focus on sunitinib. Ann. Oncol., 2007, 18(Suppl 10), x11-9.

[38] Haffner, SM.; Lehto, S.; Rönnemaa, T.; Pyörälä, K.; Laakso, M. Mortality from coronary heart disease in subjects with type 2 diabetes and in nondiabetic subjects with and without prior myocardial infarction. N. Engl. J. Med., 1998, 339(4), 229-34.

[39] Fadini, GP.; Sartore, S.; Albiero, M.; Baesso, I.; Murphy, E.; Menegolo, M.; Grego, F.; Vigili de Kreutzenberg, S.; Tiengo, A.; Agostini, C.; Avogaro, A. Number and function of endothelial progenitor cells as a marker of severity for diabetic vasculopathy. Arterioscler. Thromb. Vasc. Biol., 2006, 26(9), 2140-6.

[40] Povsic, TJ.; Goldschmidt-Clermont, PJ. Endothelial progenitor cells: markers of vascular reparative capacity. Ther. Adv. Cardiovasc. Dis., 2008, 2(3), 199-13.

[41] Sibal, L.; Aldibbiat, A.; Agarwal, SC.; Mitchell, G.; Oates, C.; Razvi, S.; Weaver, JU.; Shaw, JA.; Home, PD. Circulating endothelial progenitor cells, endothelial function, carotid intimamedia thickness and circulating markers of endothelial dysfunction in people with type 1 diabetes without macrovascular disease or microalbuminuria. Diabetologia, 2009, I(8), 1464-73.

[42] Abaci, A.; Oguzhan, A.; Kahraman, S.; Eryol, NK.; Unal, S.; Arinc, H.; Ergin, A. Effect of diabetes mellitus on formation of coronary collateral vessels. Circulation, 1999, 99(17), 2239-42.

[43] Ciulla, TA.; Amador, AG.; Zinman, B. Diabetic retinopathy and diabetic macular edema: pathophysiology, screening, and novel therapies. Diabetes Care, 2003, 26(9), 2653-64.

[44] Zimmet, P.; Alberti, KG.; Shaw, J. Global and societal implications of the diabetes epidemic. Nature, 2001, 414(6865), 782-7.

[45] Werner, N.; Kosiol, S.; Schiegl, T.; Ahlers, P.; Walenta, K.; Link, A.; Böhm, M. Nickenig G. Circulating endothelial progenitor cells and cardiovascular outcomes. N. Engl. J. Med., 2005, 353(10), 99907.

[46] Duh, E.; Aiello, LP. Vascular endothelial growth factor and diabetes: the agonist versus antagonist paradox. Diabetes, 1999, 48(10), 1899-06.

[47] Costa, C.; Incio, J.; Soares, R. Angiogenesis and chronic inflammation: cause or consequence? Angiogenesis, 2007, 10(3), 149-66.

[48] Callaghan, MJ.; Ceradini, DJ.; Gurtner, GC. Hyperglycemiainduced reactive oxygen species and impaired endothelial progenitor cell function. Antioxid. Redox. Signal., 2005, 7(11-12), 1476-82.

[49] Kränkel, N.; Adams, V.; Linke, A.; Gielen, S.; Erbs, S.; Lenk, K.; Schuler, G.; Hambrecht, R. Hyperglycemia reduces survival and impairs function of circulating blood-derived progenitor cells. Arterioscler. Thromb. Vasc. Biol., 2005, 25(4), 698-03.

[50] Vasa, M.; Fichtlscherer, S.; Aicher, A.; Adler, K.; Urbich, C.; Martin, H.; Zeiher, AM.; Dimmeler, S. Number and migratory activity of circulating endothelial progenitor cells inversely correlate with risk factors for coronary artery disease. Circ. Res., 2001, 89(1), E1-7.

[51] Creager, MA.; Luscher, TF.; Casentino, F.; Beckman, JA. Diabetes and vascular disease: pathophysiology, clinical consequences, and medical therapy, part I. Circulation 2003, 108, $1527-32$.
Yao, EH.; Yu, Y.; Fukuda, N. Oxidative stress on progenitor and stem cells in cardiovascular diseases. Curr. Pharm. Biotechnol., 2006, 7(2), 101-8.

[53] Gallagher, KA.; Liu, ZJ.; Xiao, M.; Chen, H.; Goldstein, LJ.; Buerk, DG.; Nedeau, A.; Thom, SR.; Velazquez, OC. Diabetic impairments in NO-mediated endothelial progenitor cell mobilization and homing are reversed by hyperoxia and SDF-1 alpha. J. Clin. Invest., 2007, 117(5), 1249-59.

[54] Kang, LN.; Chen, Q.; Wang, L.; Gao, L.; Meng, K.; Chen, JH.; Ferro, A.; Xu, B. Decreased Mobilization of Endothelial Progenitor Cells Contributes to Impaired neovascularization in Diabetes. Clin. Exp. Pharmacol. Physiol., 2009, [Epub ahead of print].

[55] Fadini, GP.; Sartore, S.; Schiavon, M.; Albiero, M.; Baesso, I.; Cabrelle, A.; Agostini, C.; Avogaro, A. Diabetes impairs progenitor cell mobilisation after hindlimb ischaemia-reperfusion injury in rats. Diabetologia, 2006, 49(12), 3075-84

[56] Higashi, Y.; Sasaki, S.; Nakagawa, K.; Matsuura, H.; Oshima, T.; Chayama, K. Endothelial function and oxidative stress in renovascular hypertension. N. Engl. J. Med., 2002, 346(25), 195462.

[57] Tepper, OM.; Galiano, RD.; Capla, JM.; Kalka, C.; Gagne, PJ.; Jacobowitz, GR.; Levine, JP.; Gurtner, GC. Human endothelial progenitor cells from type II diabetics exhibit impaired proliferation, adhesion, and incorporation into vascular structures. Circulation, 2002, 106(22), 2781-6.

[58] Chen, J.; Song, M.; Yu, S.; Gao, P.; Yu, Y.; Wang, H.; Huang, L. Advanced glycation endproducts alter functions and promote apoptosis in endothelial progenitor cells through receptor for advanced glycation endproducts mediate overpression of cell oxidant stress. Mol. Cell. Biochem., 2009, [Epub ahead of print].

[59] Shen, C.; Li, Q.; Zhang, YC.; Ma, G.; Feng, Y.; Zhu, Q.; Dai, Q.; Chen, Z.; Yao, Y.; Chen, L.; Jiang, Y.; Liu, N. Advanced glycation endproducts increase EPC apoptosis and decrease nitric oxide release via MAPK pathways. Biomed. Pharmacother., 2009, [Epub ahead of print].

[60] Fadini, GP.; Miorin, M.; Facco, M.; Bonamico, S.; Baesso, I.; Grego, F.; Menegolo, M.; de Kreutzenberg, V.; Tiengo, A.; Agostini, C.; Avogaro, A. Circulating endothelial progenitor cells are reduced in peripheral vascular complications of type 2 diabetes mellitus. J. Am. Coll. Cardiol., 2005, 45(9), 1449-57.

[61] Egan, CG.; Lavery, R.; Caporali, F.; Fondelli, C.; Laghi-Pasini, F.; Dotta, F.; Sorrentino, V. Generalised reduction of putative endothelial progenitors and CXCR4-positive peripheral blood cells in type 2 diabetes. Diabetologia, 2008, 51(7), 1296-05.

[62] Marfella, R.; Esposito, K.; Nappo, F.; Siniscalchi, M.; Sasso, FC.; Portoghese, M.; Di Marino, MP.; Baldi, A.; Cuzzocrea, S.; Di Filippo, C.; Barboso, G.; Baldi, F.; Rossi, F.; D’Amico, M.; Giugliano, D. Expression of angiogenic factors during acute coronary syndromes in human type 2 diabetes. Diabetes, 2004, 53(9), 238391.

[63] Vöö, S.; Dunaeva, M.; Eggermann, J.; Stadler, N.; Waltenberger, J. Diabetes mellitus impairs CD133+ progenitor cell function after myocardial infarction. J. Intern. Med., 2009, 265(2), 238-49.

[64] Yoon, YS.; Uchida, S.; Masuo, O.; Cejna, M.; Park, JS.; Gwon, HC.; Kirchmair, R.; Bahlman, F.; Walter, D.; Curry, C.; Hanley, A.; Isner, JM.; Losordo, DW. Progressive attenuation of myocardial vascular endothelial growth factor expression is a seminal event in diabetic cardiomyopathy: restoration of microvascular homeostasis and recovery of cardiac function in diabetic cardiomyopathy after replenishment of local vascular endothelial growth factor. Circulation, 2005, 111(16), 2073-85.

[65] Fadini, GP.; Sartore, S.; Baesso, I.; Lenzi, M.; Agostini, C.; Tiengo, A.; Avogaro, A. Endothelial progenitor cells and the diabetic paradox. Diabetes Care, 2006, 29(3), 714-6.

[66] Jung, C.; Rafnsson, A.; Shemyakin, A.; Böhm, F.; Pernow, J. Different subpopulations of endothelial progenitor cells and circulating apoptotic progenitor cells in patients with vascular disease and diabetes. Int. J. Cardiol., 2009, [Epub ahead of print].

[67] Ingram, DA.; Lien, IZ.; Mead, LE.; Estes, M.; Prater, DN.; DerrYellin, E.; DiMeglio, LA.; Haneline, LS. In vitro hyperglycemia or a diabetic intrauterine environment reduces neonatal endothelial colony-forming cell numbers and function. Diabetes, 2008, 57(3), 724-31.

[68] Kaufmann, P.; Alm, A. Adler's physiology of the eye. $10^{\text {th }} \mathrm{ed}$. Mosby. St. Louis, Missouri, USA, 2003, pp. 876. 
[69] Grant, MB.; May, WS.; Caballero, S.; Brown, GA.; Guthrie, SM.; Mames, RN.; Byrne, BJ.; Vaught, T.; Spoerri, PE.; Peck, AB.; Scott, EW. Adult hematopoietic stem cells provide functional hemangioblast activity during retinal neovascularization. Nat. Med., 2002, 8(6), 607-12.

[70] Goon, PK.; Lip, GY. Involvement of circulating endothelial progenitor cells and vasculogenic factors in the pathogenesis of diabetic retinopathy. Eye, 2007, 21(6), 838-9.

[71] Csaky, KG.; Baffi, JZ.; Byrnes, GA.; Wolfe, JD.; Hilmer, SC.; Flippin, J.; Cousins, SW. Recruitment of marrow-derived endothelial cells to experimental choroidal neovascularization by local expression of vascular endothelial growth factor. Exp. Eye Res., 2004, 78(6), 1107-16.

[72] Butler, JM.; Guthrie, SM.; Koc, M.; Afzal, A.; Caballero, S.; Brooks, HL.; Mames, RN.; Segal, MS.; Grant, MB.; Scott, EW. SDF-1 is both necessary and sufficient to promote proliferative retinopathy. J. Clin. Invest., 2005, 115(1), 86-93.

[73] Asnaghi, V.; Lattanzio, R.; Mazzolari, G.; Pastore, MR.; Ramoni, A.; Maestroni, A.; Ruggieri, D.; Luzi, L.; Brancato, R.; Zerbini, G. Increased clonogenic potential of circulating endothelial progenitor cells in patients with type 1 diabetes and proliferative retinopathy. Diabetologia, 2006, 49(5), 1109-11.

[74] Brunner, S.; Schernthaner, GH.; Satler, M.; Elhenicky, M.; Hoellerl, F.; Schmid-Kubista, KE.; Zeiler, F.; Binder, S.; Schernthaner,
G. Correlation of different circulating endothelial progenitor cells to stages of diabetic retinopathy: first in vivo data Invest. Ophthalmol. Vis. Sci., 2009, 50(1), 392-8.

[75] Abu El-Asrar, AM.; Struyf, S.; Verbeke, H.; Van Damme, J.; Geboes, K. Circulating bone-marrow-derived endothelial precursor cells contribute to neovascularization in diabetic epiretinal membranes. Acta Ophthalmol., 2009, [Epub ahead of print].

[76] Schoonjans, K.; Auwerx, J. Thiazolidinediones: an update. Lancet, 2000, 355(9208), 1008-10.

[77] Kusuyama, T.; Omura, T.; Nishiya, D.; Enomoto, S.; Matsumoto, R.; Murata, T.; Takeuchi, K.; Yoshikawa, J.; Yoshiyama, M. The effects of HMG-CoA reductase inhibitor on vascular progenitor cells. J. Pharmacol. Sci., 2006, 101(4), 344-9.

[78] Zhou, B.; Cao, XC.; Fang, ZH.; Zheng, CL.; Han, ZB.; Ren, H.; Poon, MC.; Han, ZC. Prevention of diabetic microangiopathy by prophylactic transplant of mobilized peripheral blood mononuclear cells. Acta. Pharmacol. Sin., 2007, 28(1), 89-97.

[79] Procházka, V.; Gumulec, J.; Chmelová, J.; Klement, P.; Klement, GL.; Jonszta, T.; Czerný, D.; Krajca, J. Autologous bone marrow stem cell transplantation in patients with end-stage chronical critical limb ischemia and diabetic foot. Vnitr. Lek., 2009, 55(3), 173-8.

(C) Carla Costa; Licensee Bentham Open.

This is an open access article licensed under the terms of the Creative Commons Attribution Non-Commercial License (http://creativecommons.org/licenses/by-nc/3.0/) which permits unrestricted, non-commercial use, distribution and reproduction in any medium, provided the work is properly cited. 